\title{
Chronic cough due to mucosal dryness in primary Sjögren's syndrome: a case report
}

\author{
Ayşe Bilge ÖZTÜRK ${ }^{1}$ \\ Erman ÖZTÜRK ${ }^{2}$ \\ Esen KASAPOĞLU²
}

\footnotetext{
${ }^{1}$ Units of Adult Allergy, Medeniyet University, Goztepe Training and Research Hospital, Istanbul, Turkey

${ }^{1}$ Medeniyet Üniversitesi, SB Göztepe Eğitim ve Araştırma Hastanesi, Erişkin Allerji Ünitesi, İstanbul, Türkiye

2 Division of Hematology, Department of Internal Medicine, Medeniyet University, Goztepe Training and Research Hospital, Istanbul, Turkey

${ }^{2}$ Medeniyet Üniversitesi, SB Göztepe Eğitim ve Araştırma Hastanesi, iç Hastalıkları Anabilim Dalı, Hematoloji Bölümü, Istanbul, Türkiye

${ }^{3}$ Division of Romatology, Department of Internal Medicine, Medeniyet University, Goztepe Training and Research Hospital, Istanbul, Turkey

${ }^{3}$ Medeniyet Üniversitesi, SB Göztepe Eğitim ve Araştırma Hastanesi, iç Hastalıkları Anabilim Dalı, Romatoloji Bölümü, İstanbul, Türkiye
}

Chronic cough is defined as a cough of $>8$ weeks of duration. A survey supported by European Respiratory Society with 18.277 subjects aged 20-48 from 16 countries world wide reported nocturnal cough in 30\%, productive cough in $10 \%$ and non-productive cough in $10 \%$ of the population (1). Chronic cough in smokers may be as a result of chronic bronchitis or as a result of irritant effect of smoke, and cough is usually due to use of ACE inhibitors, asthma, rhinosinusitis or gastrooesophageal reflux in non-smokers with normal chest radiography (2). The majority of patients referred to allergy specialist are the patients having chronic cough nonresponsive to the treatment given before they referred. The successful treatment of chronic cough leads to a major improvement in quality of life. However, treatment of chronic cough is a challenge that standard chronic cough management provide modest improvement or no improvement in some cases. A careful clinical history gives important diagnostic clues that allow for target therapeutic approach without the need for further investigation.

Primary Sjögren's syndrome is a systemic disease characterized by a chronic autoimmune inflammatory process. The most relevant finding of the disease is the presence of a focal lymphocytic infiltration of the exocrine glands. The inflammation leads to glandular destruction and atrophy that causes mucosal dryness, mainly ocular (keratoconjunctivitis sicca), oral (xerostomy), tracheal (xerotrachea) or vaginal (vaginal xerosis) (3). The most frequent respiratory symptoms are chronic cough and dyspnea in primary Sjögren's syndrome. Major histological patterns of primary Sjögren's syndrome are non specific interstitial pneumonia, bronchiolitis, atelectatic fibrosis, malignant lymphoma, amyloid and honeycomb (3). All these findings could be responsible for chronic

\section{Yazışma Adresi (Address for Correspondence)}

Dr. Ayşe Bilge ÖZTÜRK

Medeniyet Üniversitesi, SB Göztepe Eğitim ve Araştırma Hastanesi, Erişkin Allerji Ünitesi, ISTANBUL - TURKEY e-mail: aysebilgeozturk@yahoo.com 
cough in primary Sjögren's syndrome. However, the chronic cough most commonly is a result of mucosal dryness in trachea and oral mucosa (4). Here, we report a 64-year old woman applied to allergy outpatient clinic with a history of chronic cough and she was newly diagnosed as primary Sjögren's syndrome with the history of mucosal dryness in eyes, trachea and oral mucosa.

She had a history of chronic cough for 3 years. The cough was present at day and night, with little mucus production. Additional complaints included postnasal drip, and dryness in her throat. The patient was referred for persistent cough with inadequate response to previous treatment prescribed by his chest medicine physician, including antihistamines, nasal steroid sprays, inhaler steroids, antibiotics, and protonpump inhibitors. She was exsmoker for a year with the smoking history of 40 pack/year and she had isolated thrombocytosis for 3 years. Physical examination was unremarkable, with stable vital signs, including heart rate of 80 beats/min (regular), respiration of 16 breaths/min (regular), and blood pressure of 130/80 mmHg. Spirometric values were measured. Forced vital capacity (FVC) was $2.13 \mathrm{~L}$ (85\% of predicted value). FEV 1 was $1.66 \mathrm{~L}$ ( $82 \%$ of predicted value). The $\mathrm{FEV}_{1} / \mathrm{FVC}$ ratio was $87 \%$. Reversibility test was negative. Results of chest radiography, computed tomographic scans of the sinuses, and highresolution computed tomographic scans of the chest were all normal. Allergen sensitivity was not detected by skin prick test. Because the patient's symptoms did not improve with therapeutic trials for common disorders causing chronic cough, history and review of systems were revisited. On specific questioning, the patient noted that she had dryness of eyes and oral mucosa for many years. This led to consideration of Sjögren's syndrome. Rheumatology referral was made. Laboratory findings included normal values for blood count with differential, comprehensive metabolic panel including antinuclear antibody, C-reactive protein and rheumatoid factor. Thrombocyte level was $728.000 \mathrm{cell} / \mathrm{mL}$. Anti-Ro/SSA and anti-La/SSB antibodies and Schirmer test were positive. To verify the clinical diagnosis we performed a lip biopsy. Histological examination did not show any of lymphocytes infiltration in the parotid gland. She was diagnosed as primary Sjögren's syndrome with her signs, symptoms, positive auto antibodies and Schirmer test results. Treatment with chloroquine and pilocarpine provided a relief on her cough.

We conclude that a careful clinical history gives important diagnostic clues for the aetiology of chronic cough. Use ACE inhibitors, asthma, rhinosinusitis or gastrooesophageal reflux could be the main cause of chronic cough. However, we should think the other causes of the chronic cough such as primary Sjögren's syndrome in the patients having mucosal dryness who are unresponsive to therapeutic trials for common disorders causing chronic cough.

\section{CONFLICT of INTEREST}

None declared.

\section{REFERENCES}

1. Janson C, Chinn S, Jarvis D, Burney P. Determinants of cough in young adults participating in the European Community Respiratory Health Survey. Eur Respir I $2001 ; 18: 647-54$

2. Morice AH, Fontana GA, Sovijarvi AR, Pistolesi $M$, Chung $K F$, Widdicombe l, et al.; ERS Task Force. Diagnosis and management of chronic cough. Eur Respir J 2004;24(3):48192.

3. Ito I, Nagai S, Kitaichi M, Nicholson AG, Johkoh T, Noma $S$, et al. Pulmonary manifestations of primary Sjögren's syndrome: a clinical, radiologic, and pathologic study. Am J Respir Crit Care Med 2005;171(6):632-8.

4. Constantopoulos SH, Moutsopoulos HM. Respiratory system in Sjögren's syndrome. In: Talal N, Moutsopoulos HM, Kassan SS (eds). Sjögren's Syndrome: Clinical and Immunological Aspects. Berlin: Springer-Verlag, 1987:83-9. 